\title{
Testicular function following oral exposure to Tramadol and Cannabis sativa ethanol extracts in male Wistar rats
}

\author{
*Ige A.O., Oluwole D.T., Olaoye M.O., Adewoye E.O.
}

\section{Abstract}

Objective: Substance abuse is a global challenge. This study investigated the effects of two commonly abused substances, tramadol and/or Cannabis sativa ethanol extracts (ECS), on testicular function in Wistar male rats.

Methods: Twenty-animals were equally divided into 4groups that received $0.9 \% \mathrm{NaCl}(0.2 \mathrm{ml})$, tramadol $(40 \mathrm{mg} / \mathrm{kg}), \mathrm{ECS}(2 \mathrm{mg} / \mathrm{kg})$ and tramadol + ECS for 30days, respectively (daily p.o). Following anesthesia, blood samples were obtained and serum testosterone was determined. Testes and epididymis were harvested and weighed. Sperm motility, viability and counts were evaluated in the epididymis while superoxide dismutase (SOD), catalase, lactate dehydrogenase (LDH) levels and histology (Haematoxylin $\&$ Eosin) were evaluated in the testis.

Results: Sperm motility, viability, counts, testosterone level and testicular CAT was reduced in all experimental groups compared to control. Relative epididymal weights increased in tramadol only and ECS only compared to control. Testicular SOD was decreased only in the tramadol only and co-treatment (tramadol + ECS), respectively. LDH was increased in the tramadol only treatment group. Testicular histology in tramadol and co-treatment groups showed structural aberrations that are consistent with impaired spermatogenesis, antioxidant depletion and oxidative stress.

Conclusion: Abuse of tramadol and/or Cannabis sativa ethanol extracts may predispose to testicular dysfunction resulting from decline in testicular antioxidants, testicular steroidogenesis and spermatogenesis.

Keywords: Tramadol, Cannabis sativa, spermatogenic function, oxidative stress, testicular architecture

*Corresponding author

Ige, A.O.

ORCID - ID: http://orcid.org/0000-0003-2981-1256

Email:aby_ige@yahoo.com; ao.ige@mail1.ui.edu.ng

Applied and Environmental Physiology Unit, Department of Physiology, University of Ibadan, Ibadan, Nigeria. 


\title{
Fonction testiculaire suite à une exposition par voie orale à des extraits à l'éthanol de tramadol et de cannabis sativa chez des rats Wistar mâles
}

\author{
*Ige A.O., Oluwole D.T., Olaoye M.O., Adewoye E.O.
}

\begin{abstract}
Résumé
Objectif: La toxicomanie est un défi mondial. Cette étude a examiné les effets de deux substances couramment consommées, le tramadol et/ou des extraits de Cannabis sativa (ECS), sur la fonction testiculaire chez des rats mâles Wistar.
\end{abstract}

Méthodes: Vingt animaux ont été également répartis en 4 groupes qui ont reçu du $\mathrm{NaCl}$ à $0,9 \%(0,2 \mathrm{ml})$, du tramadol $(40 \mathrm{mg} / \mathrm{kg})$, de l'ECS $(2 \mathrm{mg} / \mathrm{kg})$ et du tramadol + ECS pendant 30 jours, respectivement (po journalier). Après l'anesthésie, des échantillons de sang ont été prélevés et la testostérone sérique a été déterminée. Les testicules et les épididymes ont été récoltés et pesés. La motilité, la viabilité et le nombre de spermatozoïdes ont été évalués dans l'épididyme tandis que les niveaux de superoxyde dismutase (SD), catalase, lactate déshydrogénase (CLD) et l'histologie (H et E) ont été évalués dans les testicules.

Résultats: Le poids de l'épididyme, la motilité des spermatozoïdes, la viabilité, le nombre, le niveau de testostérone et la CAT testiculaire ont été réduits dans tous les groupes expérimentaux par rapport au contrôle. La SD testiculaire n'a diminué que dans le tramadol uniquement et le co-traitement (tramadol + ECS ), respectivement. La CLD a augmenté dans le groupe de traitement tramadol uniquement. L'histologie testiculaire dans le tramadol et les groupes de Co-traitement a montré des aberrations structurelles qui sont compatibles avec une spermatogenèse altérée, une déplétion antioxydante et un stress oxydatif.

Conclusion: L'abus d'extraits à l'éthanol de tramadol et/ou de Cannabis sativa peut prédisposer à un dysfonctionnement testiculaire résultant d'une baisse des antioxydants testiculaires, de la stéroïdogenèse testiculaire et de la spermatogenèse.

Mots-clés: Tramadol, cannabis sativa, testis, stress oxydatif, dysfonctionnement testiculaire

*Corresponding author

Ige, A.O.

ORCID - ID: http://orcid.org/0000-0003-2981-1256

Email: aby_ige@yahoo.com; ao.ige@mail1.ui.edu.ng

Applied and Environmental Physiology Unit, Department of Physiology, University of Ibadan, Ibadan, Nigeria. 


\section{INTRODUCTION}

Substance abuse is a global challenge with detrimental effects on the health, wealth and security of nations (1). Substance abuse has been reported to impact negatively on reproductive health in both male and females in a variety of ways, thus contributing to the development of infertility in both sexes (2). Infertility, the inability to conceive (by women) or impregnate (by men) after 12 months of regular unprotected sexual intercourse, is found in about $15 \%$ of couples (3). Male factor infertility, a consequence of male reproductive disorders, has been reported to be the sole cause of infertility in approximately $20 \%$ of infertile couples (4). Increased infertility rates have been associated with lifestyles that increase exposure to endocrine disruptors, environmental toxins and substance abuse $(2,5)$.

In Nigeria, tramadol, an opiate, and Cannabis sativa are amongst the most abused substances and this cuts across all strata of the society $(6,7)$. Tramadol, a centrally acting opioid analgesic that is mainly used for the treatment of moderate to severe pain (8), is often abused and this has become a primary concern all over the world (9). Tramadol abuse has been associated with addictive behaviors among adolescents (10) and its addiction is recognized to cause adverse and in some cases lethal health effects (11). Cannabis sativa (also known as hemp and marijuana) on the other hand, is a green leafy plant that can be smoked, eaten with food or following solvent extraction, taken as a decoction. It has been reported to be the most commonly used and abused drug with an estimated number of 119-224 million users worldwide (12). Due to their addictive nature, medicinal use in pain management, and recreational use by adolescents there is a high probability of abuse of these two addictive agents, tramadol and Cannabis sativa, either alone or combined together.

The relationship between tramadol and sexual function appears to be controversial. Experimental studies have demonstrated a deleterious effect of tramadol on testicular function (13), while other studies suggests that in men with premature ejaculation, it has beneficial effects (9). Similarly, in experimental animals, reproductive hormonal toxicity (13) and testicular dysfunction (14) following exposure to C. sativa extracts have been reported while some studies in human have also observed no deleterious effects of $C$. sativa smoking on testicular function (15). In conditions associated with depression, anxiety disorder and pain, tramadol (16) and C. sativa $(17,18)$ has been reported to improve sexual function.

This study is therefore designed to investigate the effect of sub-chronic oral intake of tramadol and Cannabis sativa ethanol extracts (ECS) individually and in synergy on testicular function in male Wistar rats.

\section{MATERIALS AND METHODS Preparation of Plant material}

Following written permission to the National Drug Law Enforcement Agency (NDLEA), Nigeria, Cannabis sativa leaves were obtained and identified by the Department of Botany, University of Ibadan. (UIH-22809). The plant material was air-dried, pulverized to semipowdery form and Soxlet ethanol extraction of plant was carried out as described by Alagbonsi and Olayaki (13). The ethanol extract (ECS) obtained was stored at $4^{\circ} \mathrm{C}$ until use.

\section{Animals and groupings}

Twenty male albino rats $(167 \pm 25.2 \mathrm{~g})$ were housed at room temperature in well-aerated cages, fed on standard rat chow and allowed free access to drinking water ad libitum. The animals were randomly divided into 4 groups of 5 rats each. Group I, control, received normal saline $(0.2 \mathrm{ml})$, group II received tramadol $(40 \mathrm{mg} / \mathrm{kg})$ (19) while group III received ECS (2mg/kg) (13). Group IV animals were co-treated with tramadol $(40 \mathrm{mg} / \mathrm{kg})$ and ECS $(2 \mathrm{mg} / \mathrm{kg})$ simultaneously. All treatments were done orally for 30 days. The Applied and Environmental Physiology Unit, Department of Physiology, University of Ibadan approved this experiment. Animals received humane care, and procedures were in accordance with the Guide for the Care and Use of Laboratory Animals (1996, published by National Academy Press, 2101 Constitution Ave. NW, Washington, DC 20055, USA).

\section{Hormone Assay}

After treatment for 30days, blood samples were collected from all animals under light anesthesia (sodium thiopental, $50 \mathrm{mg} / \mathrm{kg}$ ) from the retro-orbital sinus into plain sample bottles. The samples were allowed to coagulate and centrifuged at $3000 \mathrm{~g}$ for $10 \mathrm{~min}$ at $4^{\circ} \mathrm{C}$ to obtain serum. The clear serum obtained was analyzed for testosterone using enzyme-linked immunosorbent assay kits obtained from Fortress Diagnostic kits, United Kingdom.

\section{Sperm analysis}

All animals were euthanized by cervical 
dislocation. The epididymis and testis were excised, cleared of fat and connective tissue and weighed to the nearest milligram. Sperm characteristics analysis was performed on spermatozoa samples collected from the caudal epididymis using Olympus research microscope (Olympus, Japan) under $\mathrm{x} 40$ microscope objectives. Progressive motility was assessed immediately. A drop of diluted sperm suspension $(5 \mu \mathrm{l})$ was placed on a pre- warmed slide and two drops of warm $2.9 \%$ sodium citrate was added and covered with cover slip. Progressive forward motility was examined and scored to the nearest 10 (20). Viability study (percentage of live spermatozoa) was done using eosin/nigrosin stain. The motile (live) sperm cells were unstained while the non-motile (dead) sperms absorbed the stain. The stained and unstained sperm cells were counted and an average value for each was recorded from which percentage viability was calculated. Sperm count was done under the microscope with the aid of the improved Neubauer haemocytometer. Counting was done in five Thoma chambers (21).

\section{Testicular damage and antioxidant status}

The testes in each animal were excised per group, weighed and the left testis homogenized on ice in $1.15 \% \mathrm{KCl}$ buffer $(\mathrm{pH}=$ 7.4). The homogenates obtained were centrifuged at $10,000 \mathrm{rpm}$ for $10 \mathrm{~min}$ at $4{ }^{\circ} \mathrm{C}$. The clear supernatant obtained was analysed for superoxide dismutase (SOD) (22), catalase (23), malondialdehyde (24), lactate dehydrogenase (ELISA method using Randox Laboratories Limited, United Kingdom) levels, respectively.

\section{Histological evaluation}

The excised right testis of each animal per group was fixed in Bouin's fluid and processed routinely for paraffin embedding. Specimen were cut into $5 \mu \mathrm{m}$ sections using a rotary microtome and processed for Hematoxylin and Eosin stain (H\&E) stains. Slides were viewed under a light microscope using different magnifications and photomicrography was made with Amscope MU900 digital camera.

\section{Statistical analysis}

Results are expressed as mean \pm SEM and were analysed using one-way analysis of variance (ANOVA) followed by Newman-Keuls post hoc test. Comparisons between control and experimental groups were carried out and the statistical differences were taken to be significant at $\mathrm{p}<0.05$.

\section{RESULTS}

Body weight in control and experimental groups

All animals showed varied increases in body weight at the end of the experiment (Day 30) when compared with their initial body weight (Day 1). Animals in the control group exhibited a $28.04 \%$ increase in body weight while animals in groups 2 (Tramadol only), 3 (ECS only) and 4 (Tramadol + ECS) showed a $15.83 \%, 15.92 \%$ and $4.51 \%$ increase in body weight respectively at end of the experiment compared to initial values within each group. The percentage increase in body weight for group 4 (Tramadol + ECS) was significantly reduced $(\mathrm{p}<0.05)$ from that obtained in control and all other treatment groups (Table $1)$.

Effect of tramadol and Cannabis sativa ethanol extract (ECS) treatment on the relative testicular and epididymal weights, sperm motility, viability and count in control and experimental groups

No significant difference was observed in relative testicular weight between control and all other experimental groups. The tramadol only and ECS only exhibited relative epididymal weights $(\%)$ of $0.52 \pm 0.09$ and $0.53 \pm 0.09$ while the Tramadol + ECS and control groups exhibited relative epididymal weights of $0.43 \pm 0.07$ and $0.47 \pm 0.08$, respectively. Sperm motility in the Tramadol only, ECS only and Tramadol + ECS were $9.6 \%, 20.7 \%$ and $14.0 \%$ reduced respectively compared to control. Percentage sperm viability and sperm counts were significantly reduced $(\mathrm{p}<0.05)$ in groups 2,3 and group 4 compared to control (Table 2).

Effect of tramadol and Cannabis sativa ethanol extract (ECS) treatment on the testicular oxidative stress status and serum testosterone in control and experimental groups

Testicular superoxide dismutase $(\mathrm{SOD})(\mathrm{U} / \mathrm{ml})$ was significantly reduced $(\mathrm{p}<0.05)$ in the tramadol only $(0.60 \pm 0.15)$ and tramadol + ECS $(0.57 \pm 0.05)$ groups respectively compared to control $(0.88 \pm 0.07)$. The SOD values observed in the ECS only group $(0.86 \pm 0.12)$ were not significantly different from control. Compared to control values, testicular malondyaldehyde (MDA) was reduced $(\mathrm{p}<0.05)$ in the tramadol + ECS treatment group. The 
MDA values observed in the tramadol only and ECS only were not significantly different from control values. A significant decline in testicular catalase activity $(\mathrm{p}<0.05)$ was observed in all treatment groups compared to control. Significant difference in testicular lactate dehydrogenase was observed in only Group II (tramadol only) compared to control. Plasma testosterone level $(\mathrm{ng} / \mathrm{ml})$ was significantly reduced $(\mathrm{p}<0.05)$ in the tramadol only $(0.60 \pm$ $0.15)$, ECS only $(2.63 \pm 1.84)$ and tramadol + ECS $(0.49 \pm 0.11)$ compared to control $(35.08 \pm$ 15.38) (Table 3).

\section{Histopathology of the testis in control and experimental groups}

The testicular sections of animals in Group I (Control group) showed normal testicular architecture, the seminiferous tubules seen are round to oval in shape, bound by a basal lamina with normal germ cell layer (spanned) that are in normal maturation stages. The spermatogonia (blue arrow) and Sertoli cells (red arrow) seen are normal. The lumen of the seminiferous tubules appears normal with presence of spermatozoa (white arrow). The interstitial spaces show normal Leydig cells (slender arrow) and mild vascular congestion (black arrow) (Fig. 1A). Group II (Tramadol only) exhibited poor testicular architecture, had irregular shapes and in some cases had ruptured seminiferous tubules. The germ cell layers in some cells are normal while the spermatogonia (blue arrow) and Sertoli cells (red arrow) seen are normal. The lumen of the seminiferous tubules appears degenerated in some cells with diminished presence of spermatozoa (white arrow). The interstitial spaces are wide, appear to lack Leydig cells and have dilated blood vessels (black arrow) (Fig. 1B). Group III (ECS only) showed normal testicular architecture, the seminiferous tubules seen are round to oval in shape, bound by a basal lamina with normal germ cell layer (spanned) that are in normal maturation stages. The lumen of the seminiferous tubules appears normal with presence of spermatozoa (white arrow). Mild vascular congestions (black arrow) are seen in the interstitium, the spermatogonia (blue arrow) and Sertoli cells (red arrow) seen are also normal (Fig 1C). In group IV (Tramadol + ECS treated), the testicular architecture is poor with seminiferous tubules that are mostly round to oval in shape and bound by a basal lamina with normal germ cell layer (spanned) that are in normal maturation stages. The lumens also appear normal with presence of spermatozoa (white arrow). The interstitial spaces show normal Leydig cells (slender arrow). They are also wide in some places and have dilated blood vessels (black arrow) (Fig. 1D).

\section{DISCUSSION}

Irrespective of age and sex, the prevalence of substance abuse continues to represent a major public health issue. Furthermore, addiction to narcotics, pain medication (25) and depression (26) has been reported to predispose to substance abuse. In developed and developing countries, the growing number of substance users continues to present with not only social but also health care problems and challenges. Tramadol and Cannabis sativa has been reported to improve sexual function in some conditions associated with depression, anxiety disorder and pain $(17,18)$, hence further increasing its likely abuse in the society.

This study shows impaired testicular function following intake of either tramadol $(40 \mathrm{mg} / \mathrm{kg}$ ), ethanol extracts of C. sativa (ECS) and co-treatment with both Tramadol and ECS. The observed severity in testicular impairment was higher in the co-treatment (tramadol + ECS) group while the extract only group had the lowest severity in testicular impairment. The testis is a reproductive organ that is reported to perform two main functions that affect fertility i.e. spermatogenesis and steroidogenesis (27). Hence any impairment in either of these functions will contribute to male infertility. This study shows an increase in the relative epididymal weights of the tramadol treated and ECS treated groups, respectively which suggests increased fluid content in these tissues likely from a disturbance of fluid balance (28). However the relative epididymal weight in the co-treatment group (tramadol +ECS) was reduced which suggests decreased spermatogenesis in the testis and decreased sperm content in the epididymis in this group (28). Furthermore, the experimental groups also exhibited a decrease in serum testosterone level, sperm motility, viability and counts respectively. These observations are consistent with other reports for tramadol (29) and C. sativa extracts (13) which attribute impairment to damage of spermatogenic cells via increased testicular levels of reactive species resulting in the production of immature sperm, low sperm count and hence impairment in testicular function. Therefore, it also likely that the severity of testicular impairment noted in the co-treatment group may be due to the synergistic effect of tramadol- and Cannabis sativa extract- 
induced testicular function impairment.

This study also shows a decline in testicular antioxidant status in the experimental groups, with a greater severity seen in the tramadol only and co-treatment group respectively, as reduced testicular SOD was accompanied by catalase reduction in these treatment groups. This suggests oxidative stress that may have resulted from an impairment of the testicular antioxidants to dismutase superoxide anion to hydrogen peroxide and decompose the hydrogen peroxide produced to water and oxygen and thus account for the histological observations in the testis of the tramadol only and co-treatment groups which show varying degrees of abnormalities ranging from poor testicular architecture, irregular shaped and in some cases ruptured seminiferous tubules to diminished spermatozoa and testicular vascular congestions. In the ECS group, SOD activity was not reduced while catalase activity was decreased. This suggests that testicular antioxidants in this group may still be able to convert superoxide anion to hydrogen peroxide but however have an impaired conversion of hydrogen peroxide to water and oxygen which ultimately would lead to testicular oxidative stress. This may account for the reduced severity in testicular structural damage observed via histology in the ECS only group. Lactate dehydrogenase, a marker of tissue damage, was also increased in tramadol only and ECS only treatment groups respectively. However for reasons that are obscured and likely due to experimental error, a reduction in testicular malodyaldehyde, a marker of tissue lipid peroxidation, was noted in all experimental groups compared to control.

It has been reported that testicular function is influenced by centrally mediated factors that involves interplay between the hypothalamus, anterior pituitary and gonads (30). Furthermore, tramadol (31) and cannabinoids (32) present in C. sativa have been reported to have receptors located in the hypothalamicpituitary-gonadal axis, which has been noted to play a role in male reproductive function. It is thus likely that tramadol and cannabinoids present in ECS, might have also impaired production and ability of hypothalamic gonadotropin-releasing hormone $(\mathrm{GnRH})$ to stimulate the production of FSH and LH secretion in the testes, and hence impair spermatogenesis in the Sertoli cells, and testosterone production by the Leydig cells, thus accounting for the reduction in testosterone level observed in this study. The role of the hypothalamo-pituitary- gonadal axis was however not investigated in this study, which represents a limitation of this study and will form the subject for further investigation in our laboratory.

All experimental groups also show a reduction in percent body weight gain compared to control. The reductions noted in the tramadol only group is consistent with other studies that show weight loss as a possible side effect of tramadol use and is attributed to its anorexic effect on the body (33). Cannabis sativa has been reported to stimulate appetite via the activation of cannabinoid receptor type 1 (CB1) leading to an increase in ghrelin (34). However studies have also shown that the appetite stimulation is not accompanied with weight gain (35) except in the presence of pathological conditions such as cancer (36). This may account for the reduction in weight gain seen in the ECS only treated animals when compared to control. The significant reduction in body weight gain in the group treated with both tramadol and ECS compared to control and other treatment groups suggests a synergy of tramadol- and Cannabis sativa-induced weight loss mechanisms in this group. It may therefore be inferred that exposure to both tramadol $(40 \mathrm{mg} / \mathrm{kg})$ and ethanol extracts of Cannabis sativa $(2 \mathrm{mg} / \mathrm{kg})$ orally may impair the bodies ability to gain weight.

\section{CONCLUSION}

In conclusion, this study suggests a predisposition to impairment of testicular function following continuous substance abuse of tramadol $(40 \mathrm{mg} / \mathrm{kg})$ and/or Cannabis sativa ethanol extracts $(2 \mathrm{mg} / \mathrm{kg})$ orally for 30days. While there are some studies that suggest beneficial effects of tramadol and Cannabis sativa in the amelioration of erectile dysfunction, care should be taken when increasing such advocacy to highlight that these beneficial effects may often be noted only in the presence of some preexisting pathology such as erectile dysfunction, be used only for a short duration and not under normal conditions.

Conflict of Interest: The authors declare no conflict of interest.

\section{REFERENCES}

1. United Nations Office on Drugs and Crime (UNODC). World Drug Report 2010. United Nations. Publication, Sales No. E.10.XI.13.

2. McKay A. Sexuality and substance use: the impact of tobacco, alcohol, and selected recreational drugs on sexual function. Can. J. Hum Sex, 2005, 14(1/2), 47-56. 
3. Borght MV, Wyns C. Fertility and infertility: Definition and epidemiology. Clin. Biochem. $2018,62,2-10$. doi.org/10.1016/j.clinbiochem.2018.03.012

4. Irvine DS. Epidemiology and aetiology of male infertility. Hum Reprod. 1998, 13, 33-44.

5. Pizzorno J. Environmental Toxins and Infertility. Integr Med (Encinitas). 2018, 17(2), 8-11.

6. Chikezie UE, Ebuenyi ID. Tramadol misuse in the Niger Delta; A review of cases presenting within a year, J. Subst. Use, 2019, 24:5, 487-491, DOI: 10.1080/14659891.2019.1604842

7. World Health Organization. The health and social effects of nonmedical cannabis use. World Health Organization, 2016.

8. Nossaman VE, Ramadhyani U, Kadowitz PJ, Nossaman BD. Advances in perioperative pain management: use of medications with dual analgesic mechanisms, tramadol \& tapentadol. Anesthesiol Clin. 2010 28(4), 647-66. doi: 10.1016/j.anclin.2010.08.009.

9. Abdel-Hamid IA, Andersson KE, Waldinger MD, Anis TH. Tramadol Abuse and Sexual Function. Sex Med. Rev. 2016 4(3), 235-246. doi: 10.1016/j.sxmr.2015.10.014.

10. Taghaddosinejad F, Mehrpour O, Afshari R, Seghatoleslami A, Abdollahi M, Dart RC. Factors related to seizure in tramadol poisoning and its blood concentration. J. Med. Toxicol., 2011, 7, 183-188.

11. Kusari S, Tatsimo SJ, Zühlke S, Spiteller M. Synthetic Origin of Tramadol in the Environment. Angew. Chem. Int. Ed. Engl. 2016, 55(1), 240-43. doi:10.1002/anie.201508646

12. UNODC. World Drug Report. Vienna: United Nations Publication (2012).

13. Alagbonsi I.A and Olayaki LA. Ameliorative effect of combined melatonin and vitamin $\mathrm{C}$ on Cannabis sativa-induced reproductive hormonal toxicity. J. Afr. Ass. Physiol. Sci. 2016, 4 (1), 1424.

14. Lotfi N, Khazaei M, Shariatzadeh SMA, Mehranjani MS, Ghanbari A. The effect of Cannabis sativa hydroalcoholic extract on sperm parameters and testis histology in rats. Int. J. Morphol. 2013, 31(1), 82-86.

15. Nassan FL, Arvizu M, Mínguez-Alarcón L, Williams PL, Attaman J, Petrozza J, Hauser R, Chavarro J. Marijuana smoking and markers of testicular function among men from a fertility centre, Hum Reprod. 2019, 34(4), 715-723, doi.org/10.1093/humrep/dez002

16. Khan AH, Rasaily D. Tramadol use in premature ejaculation: daily versus sporadic treatment. Indian J Psychol Med. 2013, 35(3), 256-259. doi:10.4103/0253-7176.119477.

17. Huang WJ, Chen WW, Zhang X. Endocannabinoid system: Role in depression, reward and pain control. Mol Med Rep. 2016, 14(4), 2899-903.

18. Gobbi G, Atkin T, Zytynski T, Wang S, Askari S, Boruff J, Ware M, Marmorstein N, Cipriani A,
Dendukuri N, Mayo N. Association of Cannabis Use in Adolescence and Risk of Depression, Anxiety, and Suicidality in Young Adulthood: A Systematic Review and Meta-analysis. JAMA Psychiatry. 2019, 76(4), 426-434.

19. El-Ghawet A. Effect of tramadol on the reproductive function of Wistar albino rats. Pelagia Res. Lib. 2015, 5, 56-64.

20. Morrissey RE, Schwetz BA, Lamb JC 4th, Ross MD, Teague JL and Morris RW. Evaluation of rodent sperm, vaginal cytology, and reproductive organ weight data from National Toxicology Program 13-week studies. Fundam Appl. Toxicol. 1988, 11(2), 343-58

21. Shi B, Haug A. Aluminum uptake by neuroblastoma cells. J. Neurochem. 1990, 55, 551-558

22. Misra HP, Fridovich I, The role of super oxide anion in the auto oxidation of epinephrine and a simple assay for super oxide dismutase, J. Biol. Chem. 1972, 247, 3170-3175.

23. Sinha AK. Colorimetric assay of catalase. Anal. Biochem. 1972, 47(2), 389-394.

24. Armstrong D, Browne R. The analysis of free radicals, lipid peroxides, antioxidant enzymes and compounds related to oxidative stress as applied to the clinical chemistry laboratory. Adv Exp Med Biol. 1994, 366, 43-58.

25. Chang Y, Compton P. Management of chronic pain with chronic opioid therapy in patients with substance use disorders. Addict Sci Clin Pract 2013, 8, 21. doi.org/10.1186/1940-0640-8-21

26. Grattan A, Sullivan MD, Saunders KW, Campbell CI, Von Korff MR. Depression and prescription opioid misuse among chronic opioid therapy recipients with no history of substance abuse. Ann F a m Med. 2012, $10(4), 304-311$. doi:10.1370/afm.1371

27. O'Hara L, Smith LB. Androgen receptor roles in spermatogenesis and infertility, Best Prac. Res. Cl. En. 2015, 29 (4), 595-605.

28. Creasy DM. Evaluation of testicular toxicology: A synopsis and discussion of the recommendations proposed by the Society of Toxicologic Pathology. Birth Defects Research Part B: Developmental and Reproductive Toxicology, 2003, 68: 408-415. doi:10.1002/bdrb.10041

29. Abdellatief RB, Elgamal DA, Mohamed EEM. Effects of chronic tramadol administration on testicular tissue in rats: an experimental study. Andrologia, 2015, 47: 674-679. doi:10.1111/and.12316

30. Plant TM. 60 Years of Neuroendocrinology: The hypothalamo-pituitary-gonadal axis. J Endocrinol. 2015, 226(2), T41-T54. doi:10.1530/JOE-15-0113

31. Seyfried O, Hester J. Opioids and endocrine dysfunction. Br J Pain. 2012, 6(1), 17-24. doi:10.1177/2049463712438299.

32. Hillard CJ. Endocannabinoids and the Endocrine System in Health and Disease. Handb Exp Pharmacol. 2015, 231, 317-339. 
doi:10.1007/978-3-319-20825-1 11.

33. Subedi M, Bajaj S, Kumar MS, Mayur YC. An overview of tramadol and its usage in pain management and future perspective, Biomed. Pharmacother. 2019, 111, 443-451. doi.org/10.1016/j.biopha.2018.12.085.

34. Zou S, Kumar U. Cannabinoid Receptors and the Endocannabinoid System: Signaling and Function in the Central Nervous System. Int J Mol $\mathrm{S}$ c i. $2018,19(3), 833$. doi:10.3390/ijms19030833.

35. Clark TM, Jones JM, Hall AG, Tabner SA, Kmiec RL. Theoretical Explanation for Reduced Body Mass Index and Obesity Rates in Cannabis Users. Cannabis Cannabinoid Res. 2018, 3(1), 259-271. doi:10.1089/can.2018.0045

36. Sansone RA, Sansone LA. Marijuana and body weight. Innov. Clin. Neurosci. 2014, 11(7-8), 50-54. 
Table 1: Effect of tramadol and Cannabis sativa treatment on the body weight in control and experimental groups

\begin{tabular}{lllllll}
\hline GROUPS & $\begin{array}{l}\text { DAY 1 } \\
(\mathbf{g})\end{array}$ & $\begin{array}{l}\text { DAY 8 } \\
(\mathbf{g})\end{array}$ & $\begin{array}{l}\text { DAY 15 } \\
(\mathbf{g})\end{array}$ & $\begin{array}{l}\text { DAY 22 } \\
(\mathbf{g})\end{array}$ & $\begin{array}{l}\text { DAY 30 } \\
(\mathbf{g})\end{array}$ & $\begin{array}{l}\text { Percent weight } \\
\text { gain within group }\end{array}$ \\
\hline Control & 144.80 & 150.40 & 159.80 & 175.20 & 185.40 & $28.04 \%$ \\
& \pm 1.56 & \pm 9.87 & \pm 6.78 & \pm 5.36 & \pm 9.14 & \\
Tramadol & 164.20 & 168.00 & 177.60 & 185.20 & 190.20 & $15.83 \% *$ \\
Only & \pm 1.24 & \pm 2.17 & \pm 4.48 & \pm 4.27 & \pm 2.63 & \\
C. sativa Only & 173.40 & 179.80 & 189.40 & 194.60 & 201.00 & $15.92 \% *$ \\
& \pm 1.53 & \pm 1.28 & \pm 1.12 & \pm 3.30 & \pm 4.97 & \\
Tramadol and & 190.60 & 189.40 & 196.20 & 203.80 & 198.60 & $4.51 \%$ *\# $^{*}$ \\
Cannabis & \pm 1.91 & \pm 3.33 & \pm 3.02 & \pm 3.15 & \pm 4.16 & \\
\hline
\end{tabular}

* indicates values that are significantly different from control.

\# indicates values that are significantly different from all other treatment groups.

Table 2: Paired testicular weight (PTW), paired epididymal weight (PEW), sperm motility, viability and count in control and experimental groups.

\begin{tabular}{llllll}
\hline GROUPS & $\begin{array}{l}\text { Relative } \\
\text { Testicular } \\
\text { Weight } \\
(\%)\end{array}$ & $\begin{array}{l}\text { Relative } \\
\text { Epididymal } \\
\text { Weight } \\
(\%)\end{array}$ & $\begin{array}{l}\text { Sperm } \\
\text { Motility } \%\end{array}$ & $\begin{array}{l}\text { Sperm } \\
\text { Viability \% }\end{array}$ & $\begin{array}{l}\text { Sperm Count } \\
\mathbf{x 1 0}^{\mathbf{6}}\end{array}$ \\
\hline $\begin{array}{l}\text { Control } \\
\text { Tramadol Only }\end{array}$ & $1.12 \pm 0.22$ & $0.47 \pm 0.08$ & $90.60 \pm 2.62$ & $83.00 \pm 1.36$ & $26.24 \pm 2.35$ \\
$\begin{array}{l}\text { C. sativa Only } \\
\text { Tramadol and }\end{array}$ & $1.29 \pm 0.21$ & $0.52 \pm 0.09$ & $82.00 \pm 1.04^{*}$ & $75.00 \pm 1.07^{*}$ & $17.28 \pm 1.84^{*}$ \\
Cannabis & $1.25 \pm 0.21$ & $0.53 \pm 0.09$ & $72.00 \pm 3.74^{*}$ & $66.00 \pm 4.00^{*}$ & $20.68 \pm 0.95^{*}$ \\
\hline
\end{tabular}

* indicates values that are significantly $(\mathrm{P}<0.05)$ different from control.

Table 3: Testicular Superoxide Dismutase, Malondialdehyde, Catalase, Lactate Dehydrogenase and serum testosterone in control and experimental groups

\begin{tabular}{llllll}
\hline GROUPS & SOD $(\mathbf{U} / \mathbf{m l})$ & MDA $(\boldsymbol{\mu M})$ & $\begin{array}{l}\text { Catalase } \\
(\boldsymbol{\mu m o l} / \mathbf{m i n} / \mathbf{m l})\end{array}$ & $\begin{array}{l}\text { LDH } \\
(\mathbf{U} / \mathbf{l})\end{array}$ & $\begin{array}{l}\text { Testosterone } \\
(\mathbf{n g} / \mathbf{m l})\end{array}$ \\
\hline Control & $0.88 \pm 0.07$ & $3.64 \pm 1.04$ & $20.27 \pm 1.39$ & $17.04 \pm 8.24$ & $35.08 \pm 15.38$ \\
Tramadol Only & $0.66 \pm 0.13^{*}$ & $2.13 \pm 0.74$ & $3.35 \pm 0.76^{*}$ & $36.97 \pm 5.78^{*}$ & $0.60 \pm 0.15^{*}$ \\
$\begin{array}{l}\text { C. } \text { sativa } \text { Only } \\
\text { Tramadol and }\end{array}$ & $0.86 \pm 0.12$ & $2.30 \pm 0.30$ & $6.61 \pm 1.81^{*}$ & $27.79 \pm 10.64$ & $2.63 \pm 1.84^{*}$ \\
Cannabis & & $1.48 \pm 0.42^{*}$ & $2.94 \pm 0.716^{*}$ & $10.87 \pm 3.28$ & $0.49 \pm 0.11^{*}$ \\
\hline
\end{tabular}

* indicates values that are significantly $(\mathrm{P}<0.05)$ different from control. 

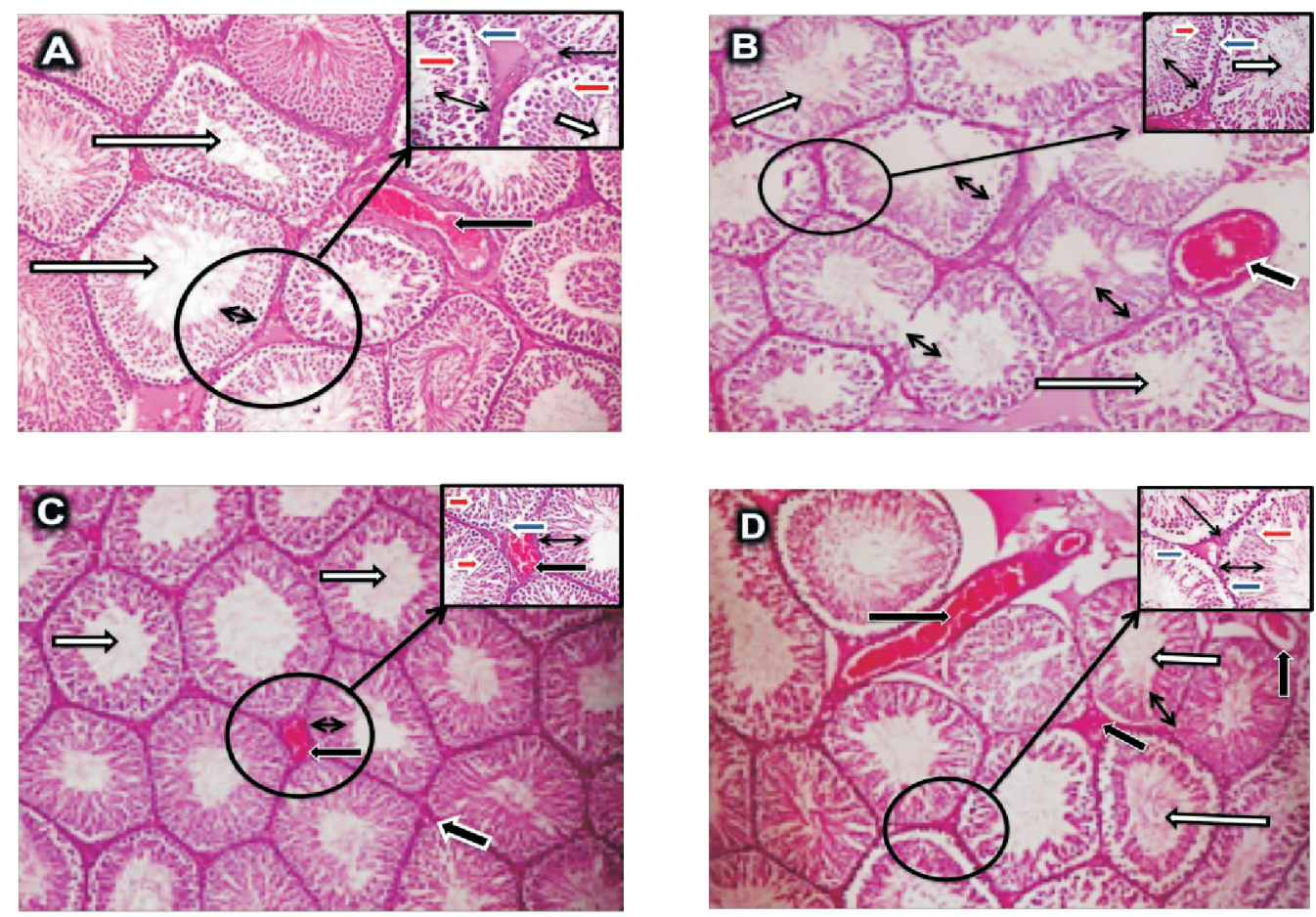

Fig. 1. (A-D) Photomicrograph of testicular sections in control and experimental groups at low magnification (x100) and high magnification (x400)

Group I (Control group) showed normal testicular architecture, the seminiferous tubules seen are round to oval in shape, bound by a basal lamina with normal germ cell layer (spanned) that are in normal maturation stages. The spermatogonia (blue arrow) and sertoli cells (red arrow) seen are normal. The lumen of the seminiferous tubules appears normal with presence of spermatozoa (white arrow). The interstitial spaces show normal leydig cells (slender arrow) and mild vascular congestion (black arrow) (Fig. 1A).

Group II (Tramadol only) exhibited poor testicular architecture and irregular shaped and in some cases ruptured seminiferous tubules. The germ cell layers in some cells are abnormal while the spermatogonia (blue arrow) and sertoli cells (red arrow) seen are abnormal. The lumen of the seminiferous tubules appears degenerated in some cells with diminished presence of spermatozoa (white arrow). The interstitial spaces are wide and appear to lack Leydig cells and have dilated blood vessels (black arrow) (Fig. 1B).

In Group III (ECS only) showed normal testicular architecture, the seminiferous tubules seen are round to oval in shape, bounded by a basal lamina with normal germ cell layer (spanned) that are in normal maturation stages. The lumen of the seminiferous tubules appears normal with presence of spermatozoa (white arrow). Mild vascular congestions (black arrow) are seen in the interstitium, the spermatogonia (blue arrow) and sertoli cells (red arrow) seen are also normal (Fig 1C).

In group IV (Tramadol + ECS treated), the testicular architecture is poor with seminiferous tubules that are mostly round to oval in shape and bound by a basal lamina with normal germ cell layer (spanned) that are in normal maturation stages. The lumens also appear normal with presence of spermatozoa (white arrow). The interstitial spaces show normal Leydig cells (slender arrow). They are also wide in some places and have dilated blood vessels (black arrow) (Fig. 1D). 